\title{
Another Critical Look at Three-Phase Catalysis
}

\author{
Xiong-Wei $\mathrm{Ni}^{1}$ \\ ${ }^{1}$ School of Engineering and Physical Sciences, Division of Chemical \\ Engineering, Heriot-Watt University, Edinburgh, United Kingdom \\ Pharmaceut Fronts 2020;2:e117-e127.
}

\begin{abstract}
Address for correspondence Xiong-Wei Ni, PhD, School of Engineering and Physical Sciences, Heriot-Watt University, Edinburgh EH14 4AS, United Kingdom (e-mail: x.ni@hw.ac.uk).
\end{abstract}

\author{
Abstract \\ Keywords \\ - phase catalysis \\ - reactor performances \\ - mass transfer \\ coefficient \\ - energy dissipation \\ rate
}

Three-phase catalysis, for example, hydrogenation, is a special branch of chemical reactions involving a hydrogen reactant (gas) and a solvent (liquid) in the presence of a metal porous catalyst (solid) to produce a liquid product. Currently, many reactors are being used for three-phase catalysis from packed bed to slurry vessel; the uniqueness for this type of reaction in countless processes is the requirement of transferring gas into liquid, as yet there is not a unified system of quantifying and comparing reactor performances. This article reviews current methodologies in carrying out such heterogeneous catalysis in different reactors and focuses on how to enhance reactor performance from gas transfer perspectives. This article also suggests that the mass transfer rate over energy dissipation may represent a fairer method for comparison of reactor performance accounting for different types/designs of reactors and catalyst structures as well as operating conditions.

\section{Introduction}

Three-phase catalysis is one of the key synthesis steps in petrochemical, chemical, cosmetic, pharmaceutical, and food industries, for instance, converting alkenes and aromatics to saturated alkanes (paraffins) and cycloalkanes (naphthenes) in petrochemical industry to reduce toxicity and reactiveness; converting unsaturated alkenes, alkynes, aldehydes, imines, and nitriles to alcohols and amines in chemical/pharmaceutical industries to produce purer products; processing vegetable oils into solid or semisolid fats, e.g., margarine, in food industry to add values, aid transportation, and lengthen products shelf times. To initiate any three-phase catalysis, e.g., hydrogenation, it requires both gas $\left(\mathrm{H}_{2}\right)$ and liquid reactants diffusing into the surfaces of solid catalysts, as illustrated in - Fig. 1 focusing on one single spherical catalyst particle of a radius $R$. The reaction mechanisms of many commercial heterogeneous catalyses, although successfully operated, are still a matter of debate and controversy, and generally consist of seven wellknown steps ${ }^{1-4}$ : (1) mass transfer of gas, e.g., $\mathrm{H}_{2}$, from bulk into the liquid phase and then to the external surface of a catalyst particle; (2) diffusion of both the dissolved $\mathrm{H}_{2}$ (gas) and organic (liquid) compounds through the pores of the catalyst to the internal catalytic surface; (3) adsorption of the gas and organic species onto the inner surfaces of the catalyst; (4) reaction on the inner surfaces of the catalyst; (5) desorption of the products from the surfaces; (6) diffusion of the products from the interior through the pores to the external surfaces; (7) mass transfer of the products from the external surfaces to the bulk fluid.

The steps (3) to (5) are regarded as the catalytic reaction, while the rest of the steps are associated with mass transfer. These reaction and transport processes occur concurrently in such catalyses. ${ }^{5,6}$ The degree of resistance in mass transfer increases significantly from liquid-solid systems to gas-solid and further to gas-liquid-solid catalysis. For liquid-solid catalysis, solid catalyst particles are readily wetted by the surrounding liquid, the dispersion of liquid into the pores of the catalyst is a relatively straightforward process. For threephase catalysis, on the other hand, the gas reactant must "travel" through the gas-gas interface, gas-liquid interface, and then the gas-solid interface before reaching the outer surfaces of the catalyst. In each of the boundary crossings, the concentration of gas is reduced, leading to the arriving concentration of $\mathrm{H}_{2}$ at the surfaces of solid catalysts $\left(\mathrm{C}_{\mathrm{H}_{2}}\right.$ surface) being significantly smaller than that of the input gas $\left(C_{\mathrm{H}_{2}}\right.$ Bulk), received

October 23, 2020

accepted

December 3, 2020
DOI https://doi.org/

10.1055/s-0040-1722219.

ISSN 2628-5088. (c) 2020. The Author(s).

This is an open access article published by Thieme under the terms of the Creative Commons Attribution License, permitting unrestricted use, distribution, and reproduction so long as the original work is properly cited. (https://creativecommons.org/licenses/by/4.0/)

Georg Thieme Verlag KG, Rüdigerstraße 14, 70469 Stuttgart,

Germany 


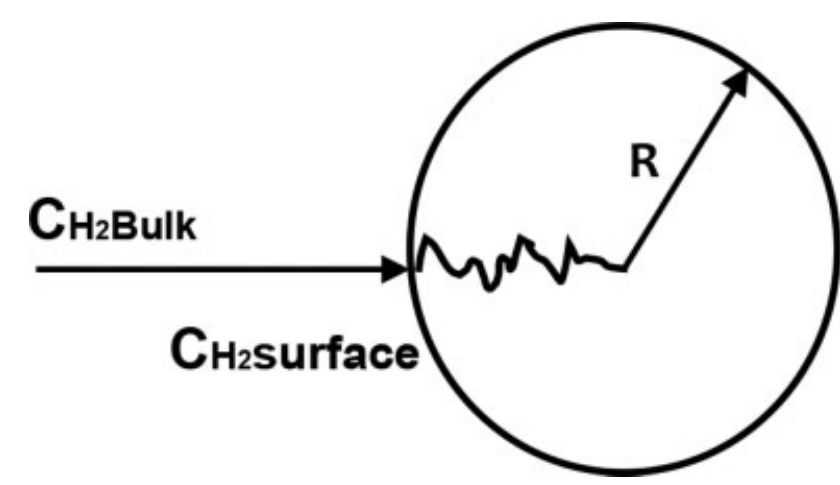

Fig. 1 Reaction mechanism of hydrogenation involving spherical solid catalyst particles.

as illustrated in - Fig. $\mathbf{2}$. Since the reaction rate is proportional to $\mathrm{C}_{\mathrm{H}_{2}}$ surface, three-phase catalysis is often severely restricted by the limitations in the aforementioned mass transfers, affecting the reaction rate, selectivity, productivity, and prolonging reaction times. ${ }^{7}$ From chemical engineering perspectives, how to minimize the difference of $\left(\mathrm{C}_{\mathrm{H}_{2}}\right.$ Bulk $-\mathrm{C}_{\mathrm{H}_{2}}$ surface $)$ is the key in ensuring effective heterogeneous catalysis.

In 1924, Murray Raney, an American engineer, discovered that by fusion of a $50: 50 \mathrm{Ni} / \mathrm{Al}$ alloy and then leaching out the Al using aqueous $\mathrm{NaOH}$, a nickel sponge was obtained, which was much more active than other commercial catalysts. ${ }^{8,9}$ The Raney nickel catalysts are often large in diameter, e.g., 1 to $10 \mathrm{~mm}$, it is easier to imagine mass transfer of gas species into these catalyst spheres. For modern metal catalysts, their sizes are usually range between micro and nanometers, thus, it becomes more difficult to envisage the aforementioned mass transfer processes taking place physically within these minute catalyst particles, but the truth is that all occur at the molecular level. Visible bubbles with a diameter from 100 s to 1000s micrometers are at the macroscopic level, similar to catalyst particles, mixing, catalyst surface structure, and physical interactions that affect the outcome of catalytic
Table 1 Dissolved hydrogen in water at $298 \mathrm{~K}^{14}$

\begin{tabular}{|l|l|l|}
\hline$P$ (bar) & $\begin{array}{l}\mathrm{g} \mathrm{H}_{2} \\
\text { dissolved/g H}\end{array}$ & $\begin{array}{l}\text { mol } \mathrm{H}_{2} \\
\text { dissolved/mol } \mathrm{H}_{2} \mathrm{O}\end{array}$ \\
\hline 1 & $1.54 \times 10^{-6}$ & $1.39 \times 10^{-5}$ \\
\hline 2 & $3.09 \times 10^{-6}$ & $2.78 \times 10^{-5}$ \\
\hline 3 & $4.62 \times 10^{-6}$ & $4.16 \times 10^{-5}$ \\
\hline 5 & $7.72 \times 10^{-6}$ & $6.94 \times 10^{-5}$ \\
\hline
\end{tabular}

reactions. In order for any reactive gas to arrive at the surfaces of catalysts that are surrounded by liquid, macroscopic bubbles must be broken into smaller and minute ones, the latter would reach equilibrium with liquid and become dissolved at the microscopic/nanoscopic level, and it is thus the dissolved gas in liquid, not visible bubbles, that holds the key for mass transfers in multiphase catalysis. From the chemical engineering viewpoint, how to increase the dissolved gas specious in liquid is an effective measure of how efficient various reactors are for carrying out heterogeneous catalyses.

Note that improving the structure of catalysts, e.g., monoliths, would enhance the areas of catalyst surfaces, and the subsequent reaction efficiency. ${ }^{10-12}$ Reactors with monolith catalyst packing are hydrodynamically superior to existing industrial reactors ${ }^{13}$; however, the physical transport process of gas dissolution into liquid must be driven by fluid mechanic forces, in combination with reactor designs/additions and catalyst structure.

Majority of three-phase catalysis is operated at elevated pressures, as pressure increases the solubility of gas into liquid. - Table 1 displays such an effect where four times more hydrogen is dissolved in water at 5 bar compared with that at 1 bar. ${ }^{14}$ However, it should be noted that the amount of hydrogen dissolved in water is measured in terms of micrograms per gram of water, i.e., parts per million. As a result, the effect of increasing pressure as a means of increasing

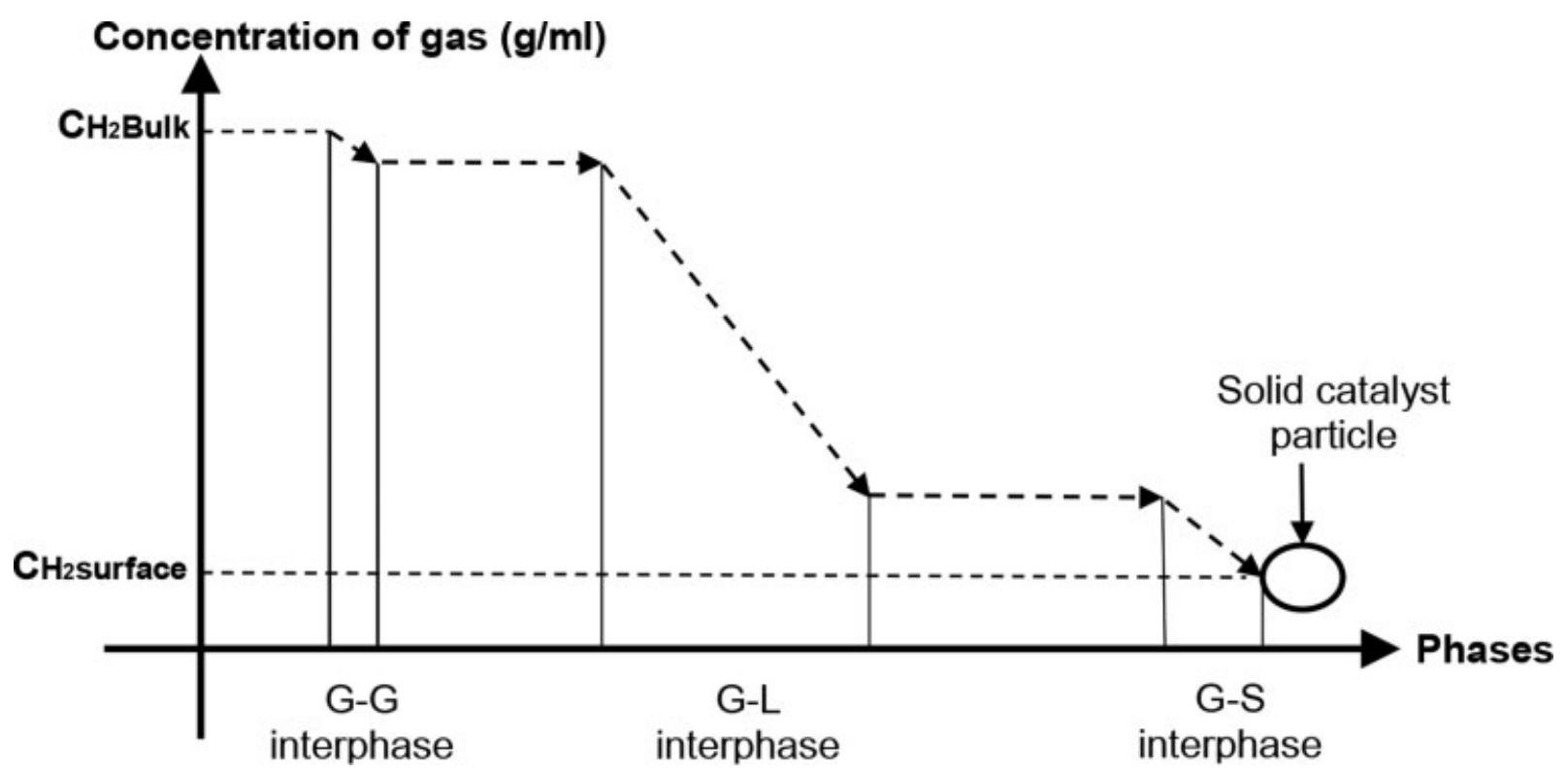

Fig. 2 Mass transfer through phase boundaries in three-phase catalysis. 
$\mathrm{C}_{\mathrm{H}_{2}}$ surface is rather small in three-phase catalysis; subsequently how to improve mass transfer of gas into liquid is THEfundamental chemical engineering parameter in most, if not all, of heterogeneous catalyses in industries. This is the focus of this review article.

\section{Reactors for Three-Phase Catalysis}

Mixing and reactor designs play a critical role in heterogeneous catalysis. The commonly used reactors in industrial multiphase catalyses are generally divided into two categories: suspended or fixed bed reactors. The former is associated with mobile catalyst particles that are suspended in reactors, also referred as slurry reactors, including bubble columns (suitable only for very small catalyst particles), agitated tanks, and three-phase fluidized beds. The fixed bed reactors involve stationary catalysts, including packed bed, trickle bed, and pulsed bed reactors. - Fig. 3 illustrates the basic principles of the two types of reactor set-ups.

In the following sections, each type of the reactors is assessed in terms of the common yardsticks for transferring gas into liquid, such as (1) mechanisms of breaking and maintaining gas bubble sizes; (2) mass transfer coefficient $\left(\mathrm{k}_{\mathrm{L}} \mathrm{a}\right)$ per energy dissipation rate $\left(\mathrm{W} \mathrm{m}^{-3}\right)$, as mass transfer coefficient alone cannot provide any meaningful comparison of reactor performances; and (3) where the dissolved gas concentration is measured in each type of contactors is critical, as it differentiates local from overall mass transfer rate.

\section{Packed Bed Reactors}

In a packed bed reactor (PBR), stationary solid catalyst particles are either packed or shelved in the reactor. The main choice for design and operation with this type of reactors is the direction of flow for both gas and liquid phases, e.g., co- or countercurrent.

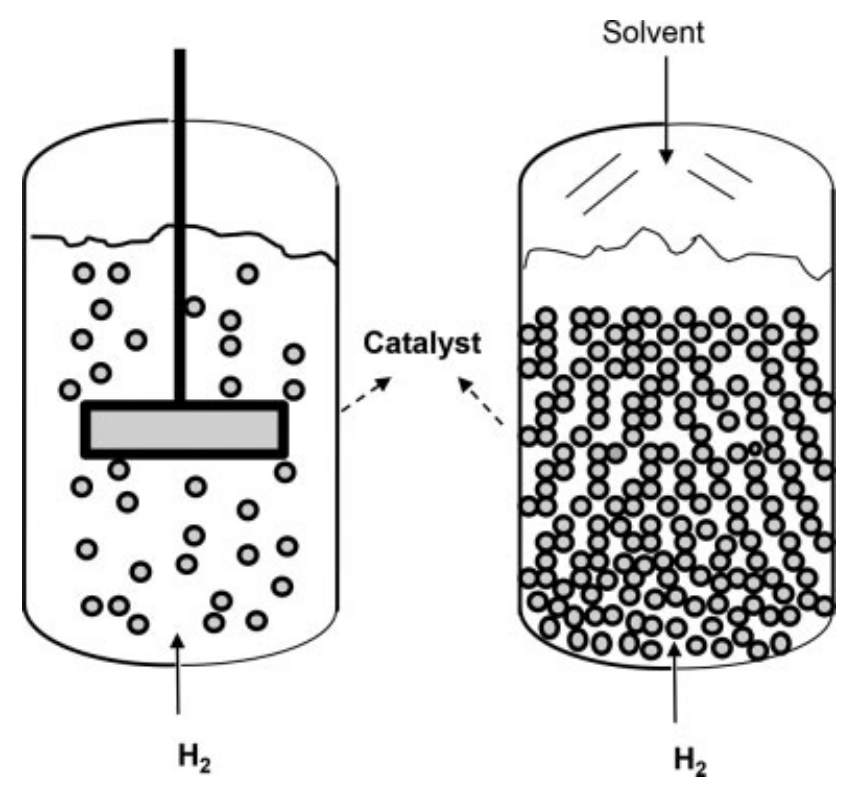

Fig. 3 Reactor type for three-phase catalysis: slurry bed (left) and packed bed (right).

\section{Trickle Bed Reactors}

A trickle bed reactor is a variant of packed bed where the liquid solvent is showered down from the top, thus increasing the surface area of the liquid, and gas can go either co-currently or counter-currently with the liquid. Hydrodynamics of trickle bed reactors were studied ${ }^{15,16}$ using transport modeling, ${ }^{17}$ computational fluid dynamics (CFD) modeling, ${ }^{18}$ electrical resistance tomography, ${ }^{19}$ as well as by high pressures. ${ }^{20}$ Due to the reliability of their operation, trickle bed reactors have won a great use in oil industry, and also found applications in $\mathrm{SO}_{2}$ oxidation, ${ }^{21}$ glucose hydrogenation over ruthenium catalyst, ${ }^{22}$ hydro-treating atmospheric residue, ${ }^{23}$ hydro-purification, ${ }^{24}$ catalytic hydro-treatment of vegetable oils, ${ }^{25}$ fuel production via Fischer-Tropsch synthesis, ${ }^{26}$ hydrogen production by aqueous-phase reforming of xylitol, ${ }^{27}$ hydrogenolysis, ${ }^{28,29}$ continuous thermal oxidation of alkenes with nitrous oxide, ${ }^{30}$ liquid-phase selective hydrogenation of methylacetylene and propadiene, ${ }^{31}$ hydrogen peroxide, ${ }^{32}$ as well as continuous operation. ${ }^{33}$

There are two possible mechanisms in trickle bed reactors for breaking down bubble sizes and initiating dissolution of gas into liquid: (1) the interactions of liquid and gas flows, (2) through the tortoise routes that are formed by the packed catalysts, the denser the solid particles, the smaller the diameters of bubbles so formed. There are however no facilities of maintaining bubble sizes in such reactors, and once gas has passed the dissolution zones, bubble coalescence occurs readily. The determinations of gas-liquid or liquid-solid mass transfer coefficients in packed beds were performed in systems involving either nonreaction schemes, for example, absorption/desorption of $\mathrm{O}_{2}$ or $\mathrm{CO}_{2}$ in water, ${ }^{34-37}$ or actual reactions. ${ }^{38,39}$ Iliuta et al compiled mass transfer data from more than 3,200 experiments in 52 gasliquid systems, with over 60 packing sizes/geometries and 17 column diameters ${ }^{40}$; however, there were neither information on where dissolved gas concentration was measured nor on energy dissipation rates in trickle bed reactors.

\section{Pulsed Trickle Bed Reactor}

In pulsed trickle bed reactors (a variant of packed bed), either gas or liquid flow is subjected to a pulse motion ${ }^{41}$ that can be generated using hydropneumatic, self-propelled, or elastic membranes. ${ }^{42}$ The pulses cause the transition to bubble flow, while the parts of the bed in between pulses reside at the transition to trickle flow. Properties of pulsing flow were studied, ${ }^{43-45}$ including hydrodynamics of trickling to pulsing flow transition ${ }^{46}$ and bubbly to pulsing flow regimes, ${ }^{47-49}$ since the majority of industrial processes operate at or near the transition from trickling to pulsing flow. The operation of trickle bed reactors at elevated temperatures was also reported. ${ }^{50}$

The same mechanisms for breaking bubbles and initiating dissolution of gas into liquid in trickle bed reactors apply to pulsed trickle beds, with an additional feature of pulsing. The purpose of pulsing liquid is effectively to "hold" bubbles for a fraction of time (e.g., $0.5 \mathrm{~Hz}$ ), this enhances overall heat and mass transport while reducing axial dispersion. Keeping all other parameters constant, reactor operation in the presence of pulses resulted in up to $30 \%$ increase in reaction rate, ${ }^{44} 15 \%$ increase in styrene concentration, ${ }^{51}$ and $45 \%$ improvement in 
styrene selectivity in hydrogenation of phenylacetylene over $\mathrm{Pt} / \mathrm{\gamma}-\mathrm{Al}_{2} \mathrm{O}_{3}$ catalyst compared with that without. Some mass transfer data in pulsed trickle bed reactors were reported, ${ }^{52-54}$ once again, no information was given on both where dissolved gas concentration was measured and energy dissipation rate.

\section{Slurry Bed Reactors}

In slurry bed reactors, solid catalyst particles are suspended in a liquid solution. There are many means of creating slurry suspension, e.g., mechanic, pneumatic, oscillatory, and combinations of flow directions of gas and liquid phases.

\section{Stirred Tank Reactors}

Stirred tank reactors (STRs) are the widely used industrial workhorse for chemical reactions, including heterogeneous catalysis, ${ }^{55-57}$ catalytic cracking, ${ }^{58}$ catalytic foaming, ${ }^{59}$ and Fischer-Tropsch synthesis, ${ }^{60}$ just to name but a few. In terms of operation, solvent and catalyst particles are added to the tank, and impeller or impellers are used for mixing and suspending mobile catalyst solids. A sparger is implemented for introducing gas, either from the top or the bottom, with or without recycling of the product stream back to the reactor.

The mechanisms of breaking gas bubbles in STR usually include the rotating motions of impeller(s) and the interactions of fluid with the presence of wall baffles. In laboratory-scale STRs, mixing is regarded as uniform, thus, the dissolved gas concentration measured anywhere in the reactor can be used for the determination of the overall mass transfer coefficient. With the increase of reactor volume, however, a gradient in bubble sizes is often generated, in which the smaller bubbles appear near the tip of the impellor, and the larger bubbles appear elsewhere. The balance between bubble breaking and coalescence is determined by the hydrodynamic force of impeller rotation in the presence of mixing aids, e.g., wall baffles, thus the designs of impeller and turbulence promoter ${ }^{61}$ are critical in providing more uniform bubble size, and in turn the higher mass transfer rate, ${ }^{62,63}$ e.g., mass transfer using either a dual impeller $^{64}$ or radial-axial impeller combination ${ }^{65}$ was 15 to $35 \%$ higher in comparison to a single impeller. Mass transfer of a gas into a liquid has intensively been studied in STR, such as air in water, ${ }^{66-68} \mathrm{H}_{2}$ in water, ${ }^{69-72} \mathrm{O}_{2}$ in liquid hydrocarbons, ${ }^{73}$ and in $n$-octacosane processes, ${ }^{74}$ in fermentation vessels, ${ }^{75}$ in gas-liquid-solid systems, ${ }^{76-78}$ and in scale-up STRs. ${ }^{79,80}$ Modeling of gas-liquid mass transfer ${ }^{81}$ was performed using an Euler-Lagrange approach ${ }^{82}$ and CFD. ${ }^{83}$ Additionally, liquid-solid mass transfer ${ }^{84,85}$ and solid-liquid mass transfer ${ }^{86}$ were also reported in STR.

Energy dissipation rates in STR takes the form of Equation 1:

$$
\frac{P}{V}=\frac{P_{o} \rho N^{3} D_{S}^{5}}{\pi D_{v}^{2} L_{h} / 4} \quad \text { (Equation 1) }
$$

Where $P / V$ is the energy dissipation rate per volume (W $\left.\mathrm{m}^{-3}\right), P_{0}$ the power number for the impeller depending on the impeller type and dimensions, $N$ the rotational speed of the stirrer $\left(\mathrm{s}^{-1}\right), L_{\mathrm{h}}$ and $\rho$ are the height $(\mathrm{m})$ and density $\left(\mathrm{kg} \mathrm{m}^{-3}\right)$ of the liquid in the reactor, and $D_{\mathrm{s}}$ and $D_{\mathrm{v}}$ the diameters of the agitator and the vessel $(\mathrm{m})$, respectively. This is the energy that is received and utilized by the reaction media to achieve the measured mass transfer rate in the said reactor. ${ }^{87-94}$ Available mass transfer and energy dissipation data are used for comparison in a later section.

\section{Bubble Column}

A bubble column by definition consists of a column filled with liquid and solid catalyst particles with gas being sparged from the bottom. The hydrodynamics and heat/mass transfer of slurry bubble columns were reported. ${ }^{68,95-106}$ In addition, slurry bubble columns were also used in Fischer-Tropsch synthesis, ${ }^{107,108} \mathrm{CO}$ methanation over La-promoted $\mathrm{Ni} / \mathrm{Al}_{2} \mathrm{O}_{3}$ catalyst $^{109}$ and green fuel production via hydrocracking of vegetable oil. ${ }^{110}$ It should however be noted that the bubble column itself has no physical mechanisms of breaking bubbles as well as preventing bubbles from coalescing, and various restrictions, delays, and recycles are implemented to aid the physical process of bubble breaking, e.g., down pipes, loop, jet, and pulsing.

Jet flow/loop reactors are the variants of bubble columns; the implementation of jet is to break gas bubbles and the looping is to increase the time for dissolution of gas. In jet loop reactors, an external pump is used to circulate liquid (along with the catalyst and often some gas) through an ejector type nozzle, as such gas-inducing nozzle is a critical design component of jet loop reactors, ${ }^{111,112}$ Fundamental scientific studies of flow in and out of a nozzle were reported in terms of mixing, ${ }^{113,114}$ hydrodynamics, ${ }^{115-117}$ bubble size distribution, ${ }^{118}$ mass transfer, ${ }^{119,120}$ as well as reaction kinetics. ${ }^{121}$

The jet in jet loop reactor sends liquid plume downwards, causing dispersion and entrainment of minute bubbles, this is where the maximum dissolution of gas into liquid and excellent gas-liquid mass transfer take place. When the jet plume reaches the bottom of the down-flow, the jet stream comes up, leading to bubble coalescence and visible bubbles rising. Effectively the dissolution zone is the length of the jet core. A study by Mandal ${ }^{114}$ shows that the core length was 30 to $45 \mathrm{~mm}$ in a $1,500-\mathrm{mm}$ tall column of a diameter of $52 \mathrm{~mm}$, i.e., approximately $3 \%$ of the full length, although the core length can reach $50 \%$ of the full reactor length in industrial-scale operations. Dissolved gas concentrations were mainly measured at the tail end of the core, where bubble sizes were generally from 1 to $6 \mathrm{~mm} .^{122,123}$ The energy requirement for forming such a jet is usually high, e.g., 1.2 to $1.5 \mathrm{~m}^{3} / \mathrm{h}$ for liquid flow and 0.25 to $1 \mathrm{~m}^{3}$ / $\mathrm{h}$ for gas flow in a jet loop reactor of $200 \mathrm{~mm}$ diameter and $700 \mathrm{~mm}$ tall $^{118}$; however, neither equations nor data were given on energy dissipation rates due to the combination of wideranging fluid mechanical zones with nonstandardized designs of jet promoters for this type of reactors.

Jet loop reactors have been used for model reactions such as hydrogenation, chlorination, phosgenation, hydroformylation, ${ }^{124,125}$ as well as for processes of $\mathrm{CO}_{2}$ absorption, ${ }^{126}$ anaerobic codigestion of olive mill wastewater and liquid poultry manure, ${ }^{127}$ treatment of slaughterhouse wastewater, ${ }^{128}$ imidacloprid preparation, ${ }^{129}$ and microbial fermentation. ${ }^{130}$ 


\section{Fluidized-Bed Catalytic Reactors}

Heterogeneous catalysis has also been performed in fluidized-bed reactors where the gas reactant is bubbling through a liquid bed containing a solid catalyst. ${ }^{131}$ The desirable features of a fluidized bed reactor can briefly be summarized as its the favorable heat transfer, temperature uniformity, high effectiveness factors, low pressure drop, and ability to add/remove catalysts, and some of the disadvantages are entrainment, attrition, wear, as well as nonuniform residence time distributions, and unpredictability. ${ }^{131}$ In reality, the design and scale-up of fluidized-bed reactors rely heavily on experience, mechanistic understanding, and models. ${ }^{132}$ There is a void in the literature for the evaluation of energy dissipation rate in fluidized bed reactors.

In summary, the advantages of PBRs are (1) there is lesser demand on particle size of catalyst; (2) it is relatively easy to design this type of reactors; and (3) there is no need for catalyst separation after reaction, reducing unit operation and associated requirement for energy and labor. The major drawback for stationary catalysts is that the required quantity of the catalyst is significantly higher in comparison to mobile catalyst arrangement for the same conversion due to reduced surface areas of the catalysts. In addition, bubble sizes are relatively large, as there is generally lack of means of holding small bubbles, leading to lower mass transfer capability and longer reaction times.

For slurry bed reactors, there are mechanic means of breaking bubbles and achieving gas dissolution, thus increasing mass transfer and reaction rates; mobile catalysts offer significantly higher surface areas, leading to much less catalyst and shorter reaction time to achieve the same conversion in comparison to stationary catalysts. The shortcoming for this type of operation is that a separation of solid catalyst particles is mandatory at the end of reaction, leading to potential loss of catalyst due to attrition. Filtered catalyst particles can be reused for a few times depending on processes.

\section{Micro Bubbles}

Process intensification in multiphase reactors have been used $^{133-135}$ with various mechanisms, e.g., continuous flow mixing vessels, ${ }^{136}$ vorticial ciliary flows, ${ }^{137}$ micromesh, ${ }^{138}$ microbubble generators, ${ }^{139}$ microreactors, ${ }^{140-143}$ and in scale-up flow reactors. ${ }^{144}$ The key feature of these intensified devices is the ability of producing fine and minute bubbles; consistently, some show the capability of maintaining fine bubble sizes, leading to enhanced mass transfer rates. However, currently, there are no publications on energy dissipation rates in these new/novel reactors.

\section{Oscillatory Baffled Reactors}

Oscillatory baffled reactors (OBR) generally consist of a jacketed cylindrical column and a set of orifice baffles. The up and down movement of the baffle set within the column generates intensive eddy current that moves fluids from wall to center, creating equal radial and axial velocity components, which is the essential measure of uniform mixing. The intensity of mixing in a batch OBR can be controlled by varying either oscillation amplitude or/and frequency when the orifice diameter and baffle spacing are fixed. Oscillatory amplitudes from half to one baffled cell length and oscillation frequency from 1 to $8 \mathrm{~Hz}$ can be employed, the latter is much higher than that in pulsed trickle bed reactors. The energy dissipation rate in OBR was developed by assessing inertial and frictional effects of the flow together with pressure drop due to a static head, ${ }^{145-148}$ as in Equation 2:

$$
\frac{P}{V}=\frac{2}{3} \frac{N_{b} \rho}{\pi C_{D}^{2}} \frac{1-\alpha^{2}}{\alpha^{2}} x_{o}^{3} \omega^{3}\left(\mathrm{~W} \mathrm{~m}^{-3}\right) \text { (Equation 2) }
$$

Where $N_{\mathrm{b}}$ is the number of baffles per unit length in OBR $\left(\mathrm{m}^{-1}\right), \alpha$ the ratio of the effective orifice area to the tube area, $x_{0}$ the oscillation amplitude (m), $\omega$ the angular oscillation frequency (radians s ${ }^{-1}$ ) and $C_{D}$ the orifice discharge coefficient.

When gas is involved, gas bubbles are broken down by the formed vortices; the reciprocal movement of the baffles also holds and maintains bubble sizes. When compared with mass transfer of air in water, ${ }^{149-151}$ air in cultures, ${ }^{152} \mathrm{O}_{2}$ in water, ${ }^{153,154}$ ozone in water, ${ }^{155,156}$ and $\mathrm{CO}_{2}$ in water ${ }^{157}$ in STRs or bubble columns, $\mathrm{k}_{\mathrm{L}}$ a values in OBR were much improved, which was attributed to three distinct features: (1) smaller and more uniform bubble sizes due to the mechanism of maintaining bubble sizes; (2) higher gas hold-up, as a foaming layer at the top of the column acts as a "blanket" to prevent minute bubbles from disengaging, and the oscillatory motion drags these bubbles back into the liquid; and (3) significantly prolonged residence times of bubbles due to the reciprocal motion of eddies.

The above key features are manifested in a comparative study of catalytic hydrogenation of 3-butyn-2-ol over Pd/ $\mathrm{Al}_{2} \mathrm{O}_{3}$ catalyst to generate 3-buten-2-ol (an intermediate) in both a commercially available stirred tank PARR reactor (PARR in short) and an OBR, ${ }^{158}$ where an increase in the initial reaction rate $\left(r_{0}\right)$ with the increase of energy dissipation rate (stirring speed) is seen up to $29,500 \mathrm{~W} \mathrm{~m}^{-3}$ in the PARR reactor ( - Fig. 4), beyond which $r_{0}$ is unaffected, indicating that the capacity of mixing in terms of stirring speed in the PARR has reached its ceiling and no longer affects the reaction rate.

Under the same reaction conditions, rising profiles of the initial reaction rate against energy dissipation are still seen for all pressures tested in the OBR (-Fig. 5), indicating that the capacity of mixing is not only significantly larger, but also more energy efficient than the PARR reactor, for example, approximately six times less energy dissipation in the OBR was required to achieve the same reaction rate obtained in the PARR working at the same pressure or approximately three times less energy dissipation if the operating pressure in the OBR was halved.

\section{Comparison}

In this article, several reactors for heterogeneous catalysis have been introduced, each involves different physical 


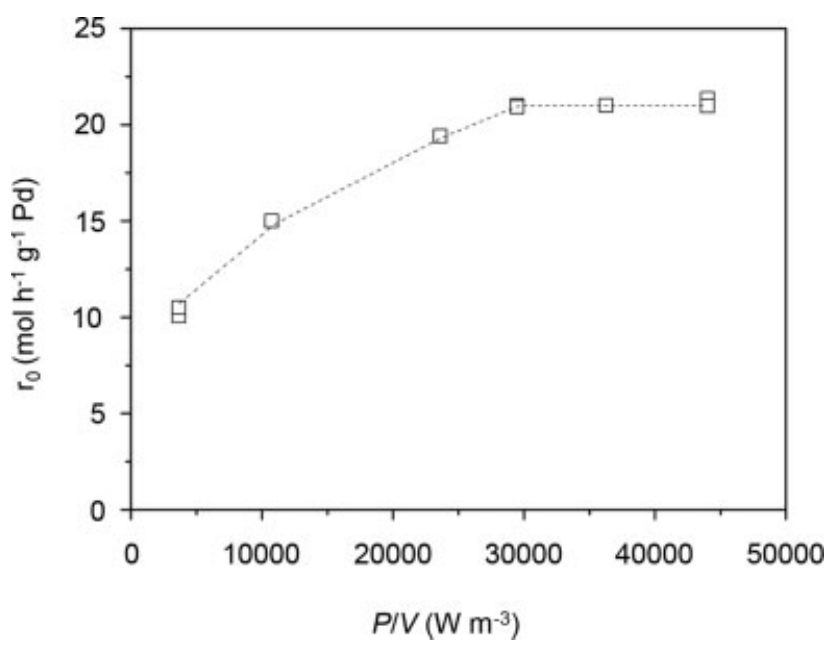

Fig. 4 Effect of energy dissipation $(P / V)$ on initial reactor rate $\left(r_{0}\right)$ in the stirred tank PARR reactor at 1 bar. ${ }^{148}$

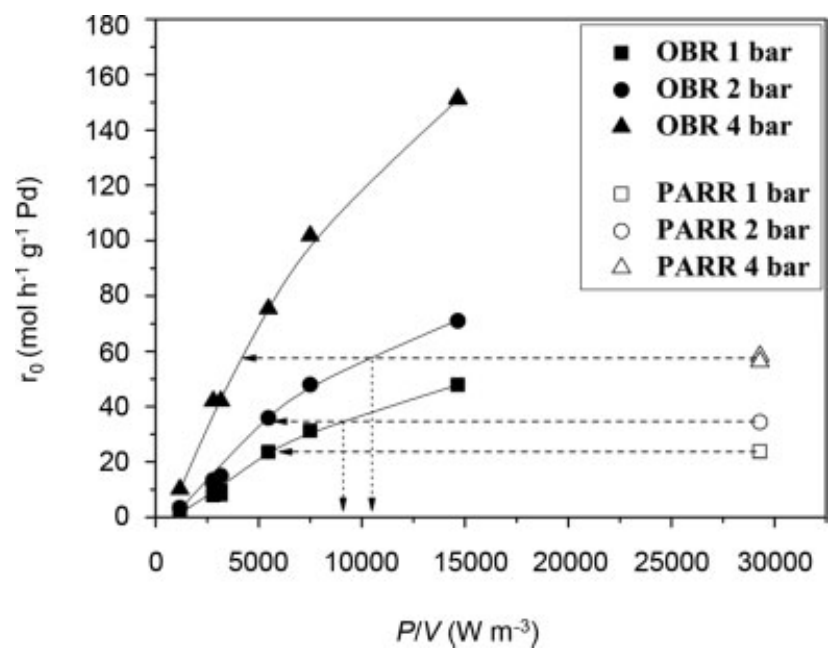

Fig. 5 Effect of energy density $(P / V)$ on initial reaction rate $\left(r_{0}\right)$ at different pressures in PARR and OBR. Working conditions: initial molar ratio 3-butyn-2-ol/Pd $=1,360$ and temperature $=323 \mathrm{~K}^{148} \mathrm{OBR}$, oscillatory baffled reactor.

designs and operating conditions. How could reactor performances be compared and what would be the common basis for such a comparison? Using the $100 \mathrm{~m}$ sprint as an example, if you race against Usain Bolt, Usain Bolt will win every time, because Usain Bolt is the fastest sprinter in the world, while you are an amateur runner. We accept the outcome without questioning. If you challenge Usain Bolt with you on a motor bike, you will win the race. This leads to the key question: what is the common basis for comparison? From the above example, power consumed by the motor bike is more than that by the human being, and the sprint time divided by the power consumption would provide a levelplaying field for comparison of different racing modes; in this case Usain Bolt will win it again. The exact principles are applied here. The basis is the energy dissipation rate $\left(\mathrm{W} \mathrm{m}^{-3}\right)$ that is received by the reaction media in a given reactor, which is neither the electric power of the motor that is used for stirring in STRs nor the power of pump that is employed for generating jets in jet loop reactors. Using either mass transfer coefficient or bubble mean size alone does not serve any meaningful purpose of comparison, since higher energy dissipation experienced by the reaction mixture generally leads to higher mass transfer rates. By dividing mass transfer coefficient over energy dissipation that is consumed by reaction media to generate the measured transfer rate would offer a fairer and better comparison of reactor performances, counting for different designs and operating conditions. This ratio is used in this article.

While there are plentiful research papers on the evaluation of energy dissipation in both STRs and OBRs, no research articles are found for other types of both slurry and packed bed contactors. In some cases, data of mass transfer coefficient or mean bubble sizes or gas hold-up were presented as a function of energy dissipation, but no information was given on how these dissipation rates were derived. Taking a leap of faith, $\boldsymbol{\sim}$ Table 2 compiles the ratio of $\mathrm{k}_{\mathrm{L}} \mathrm{a}$ over their corresponding energy dissipations as the key indicator (last column). Note that the lowest energy dissipation data were taken for comparison in $\mathbf{- T a b l e} \mathbf{2}$, and this is due to the unavoidable fact in gas-liquid systems where the percentage increase in mass transfer coefficient is much smaller than that in energy dissipation (mixing), e.g., often 100\% increase in energy dissipation leads to 1 to $5 \%$ increase in mass transfer rates.

While the ratio of $\mathrm{k}_{\mathrm{L}}$ a over $(P / V)$ in - Table 2 gives the indicative comparison of the capability of delivering gas to liquid mass transfer for different types of gas-liquid contactors, there are three factors to note:

- Each reactor type has means of breaking bubbles; it is however the mechanism of maintaining achieved bubble sizes that are critical to the overall mass transfer rate, as gas bubbles coalesce naturally. Reactors with higher ratios of mass transfer over energy dissipation are generally equipped with better mechanisms of maintaining bubble sizes.

- Most gas-liquid contactors exhibit nonuniform mixing patterns, or have different fluid dynamic zones, where exactly the dissolved gas concentration was measured in a given reactor can have significant impact on the determination of the overall mass transfer rate; unfortunately very few details in this aspect were disclosed in published papers.

- The contribution of static pressure head, e.g., $\rho g u_{g}$, or


dissipation is generally very small; the inclusion of such a term makes little difference in energy dissipation data compared with the exclusion of it.

In summary, heterogeneous catalysis covers countless processes involving three phases. Breaking and maintaining minute bubble sizes throughout each reaction are the unique chemical engineering challenge, yet at present, there is not a unified system of quantifying and comparing reactor performances. Profiles of mean bubble size, gas hold-up, $\mathrm{k}_{\mathrm{L}} \mathrm{a}$ as function of aeration rates, jet velocity, stirring rate, nozzle diameter, etc. are rather bespoke, and have little value for any meaningful comparison. In this article, the mass transfer rate over energy dissipation is proposed as a fairer method for comparison of 
Table 2 Comparison of mass transfer rates based on energy dissipation

\begin{tabular}{|c|c|c|c|c|c|}
\hline Reference & Reactor type & Energy dissipation $(P / V)$ equation & $P / V\left(\mathrm{~kW} \mathrm{~m}^{-3}\right)$ & $\mathrm{k}_{\mathrm{L}} \mathrm{a}\left(\mathrm{s}^{-1}\right)$ & Ratio $\mathrm{k}_{\mathrm{L}} a /(P / V)$ \\
\hline 159 & Sparged stirred tank & $\begin{array}{l}P / V=\left(P_{0} f^{3} D^{5} \rho N+\rho g v_{\mathrm{g}} V_{\mathrm{L}}\right) / V_{\mathrm{L}} \\
P_{0} \text { - power number } \\
f \text { - agitation speed } \\
N \text { - number of impellor } \\
D \text { - diameter of impellor } \\
V_{\mathrm{g}} \text { - gas superficial velocity } \\
V_{\mathrm{L}} \text { - volume of liquid }\end{array}$ & 0.1 & 0.02 & 0.2 \\
\hline 160 & Sparged stirred tanks & $\begin{array}{l}P / V=\alpha\left(P_{0}^{2} N D^{3} / Q^{0.56}\right)^{\beta} / V_{\mathrm{L}} \\
\mathrm{N}-\text { agitation speed } \\
D \text { - stirrer diameter } \\
Q \text { - gas flow rate } \\
P_{0} \text {-energy input in unaerated system } \\
\alpha \text { and } \beta \text { depend on type } \\
\text { and numbers of stirrer }\end{array}$ & 0.15 & 0.002 & 0.133 \\
\hline 89 & Sparged stirred tanks & $\begin{array}{l}P / V=\left(2 \pi N M+\rho_{\mathrm{L}} g H_{\mathrm{s}} Q_{\mathrm{g}}\right) / V_{\mathrm{L}} \\
N \text { - agitation speed } \\
M \text { - torque } \\
H_{\mathrm{s}} \text { - liquid height } \\
Q_{\mathrm{g}} \text { - gas flow rate } \\
V_{\mathrm{L}} \text { - liquid volume }\end{array}$ & 1.3 & 0.04 & 0.03 \\
\hline 161 & Sparged stirred tank & $\begin{array}{l}P / V=2 \pi N M / V_{\mathrm{L}} \\
N \text { - agitation speed } \\
M \text { - torque } \\
V_{\mathrm{L}} \text { - liquid volume }\end{array}$ & 0.7 & 0.019 & 0.027 \\
\hline 162 & Jet flow loop & & 0.8 & 0.014 & 0.018 \\
\hline 120 & Jet loop & & 2 & 0.6 & 0.3 \\
\hline 163 & $\begin{array}{l}\text { Plunging jet } \\
\text { bubble column }\end{array}$ & & 8 & 0.2 & 0.025 \\
\hline 111 & Gas-liquid ejector & & 20 & 1.1 & 0.055 \\
\hline \multirow[t]{6}{*}{164} & $\begin{array}{l}\text { Microbubble } \\
\text { nozzle }\end{array}$ & & 0.05 & 0.002 & 0.04 \\
\hline & Perforated plate & & 0.005 & 0.0002 & 0.04 \\
\hline & Spiral liquid flow & & 1.3 & 0.001 & 0.008 \\
\hline & Venturi & & 1 & 0.0003 & 0.003 \\
\hline & Ejector & & 7 & 0.0004 & 0.00006 \\
\hline & $\begin{array}{l}\text { Pressurized } \\
\text { dissolution }\end{array}$ & & 10 & 0.001 & 0.0001 \\
\hline 138 & $\begin{array}{l}\text { Jet array downflow } \\
\text { bubble column }\end{array}$ & & 1.254 & 0.139 & 0.111 \\
\hline 149 & $\begin{array}{l}\text { Oscillatory } \\
\text { baffled column }\end{array}$ & $\begin{array}{l}(P / V)=2 p N_{b}\left(1-\alpha^{2}\right) x_{0}^{3} \omega^{3} /\left(3 \pi C_{D}^{2} \alpha^{2}\right) \\
N_{b}-\text { number of baffles per unit length } \\
C_{D} \text { - orifice discharge coefficient } \\
\alpha \text { - baffle-free cross-sectional area } \\
x_{0} \text {-oscillation amplitude } \\
\omega-\text { angular frequency of oscillation }\end{array}$ & 0.05 & 0.02 & 0.4 \\
\hline 153 & $\begin{array}{l}\text { Oscillatory } \\
\text { baffled column }\end{array}$ & $\begin{array}{l}(P / V)_{0}=2 p N_{b}\left(1-\alpha^{2}\right) x_{0}^{3} \omega^{3} /\left(3 \pi C_{D}^{2} \alpha^{2}\right) \\
N_{b}-\text { number of baffles per unit length } \\
C_{D} \text { - orifice discharge coefficient } \\
\alpha \text { - baffle-free cross-sectional area } \\
x_{0} \text {-oscillation amplitude } \\
\omega-\text { angular frequency of oscillation } \\
(P / V)_{\mathrm{B}}=\rho g u_{\mathrm{g}} \\
P / V=(P / V)_{0}+(P / V)_{\mathrm{B}}\end{array}$ & 0.02 & 0.005 & 0.25 \\
\hline
\end{tabular}


reactor performance accounting for different types/designs of reactors and catalyst structures as well as operating conditions. Hope more papers on energy dissipation rates for both existing and new-type reactors are emerging to fill the gap.

\section{Funding}

None.

\section{Conflict of Interest}

The authors declare no conflict of interest.

\section{References}

1 Langmuir I. The mechanism of the catalytic action of platinum in the reactions $2 \mathrm{CO}+\mathrm{O}_{2}=2 \mathrm{CO}_{2}$ and $2 \mathrm{H}_{2}+\mathrm{O}_{2}=2 \mathrm{H}_{2} \mathrm{O}$. Trans Faraday Soc 1922;17:621-654

2 Horiuti I, Polanyi M. Exchange reactions of hydrogen on metallic catalysts. Trans Faraday Soc 1934;30:1164-1172

3 Boudart M. Concepts in heterogeneous catalysis. In: Gomer R, ed. Interactions on Metal Surfaces. Berlin, Heidelberg: Springer Berlin Heidelberg; 1975:275-298

4 Thomas JM, Thomas WJ, Salzberg H. Introduction to the principles of heterogeneous catalysis. J Electrochem Soc 1967;114 (11):279C

5 Beller M, Penken A, van Santen R. Catalysis. From Principles to Applications Weinheim, Germany: Wiley-VCH; 2012:642

6 Alper E. Mass Transfer with Chemical Reaction in Multiphase Systems. Netherlands: Springer; 1983

7 Yuan G, Keane MA. Liquid phase catalytic hydrodechlorination of 2,4-dichlorophenol over carbon supported palladium: an evaluation of transport limitations. Chem Eng Sci 2003;58(02): 257-267

8 Inventor RM. Method of Preparing Catalytic Material. United States Patent 1915473. June, 1933

9 Covert LW, Adkins H. Nickel by the Raney process as a catalyst of hydrogenation. J Am Chem Soc 1932;54(10):4116-4117

10 Cybulski A, Moulijn JA. Structured Catalysts and Reactors. 2nd ed. Boca Raton: CRC Press Taylor \& Francis Group; 2005:559-596

11 Moulijn JA, Kreutzer MT, Nijhuis AT, Kapteijn F. ChemInform Abstract: Monolithic Catalysts and Reactors: High Precision with Low Energy Consumption. New York, NY: Elsevier Science Technology; 2011

12 Kapteijn F, Nijhuis TA, Heiszwolf JJ, Moulijn JA. New non-traditional multiphase catalytic reactors based on monolithic structures. Catal Today 2001;66(2-4):133-144

13 Roy S, Bauer T, Al-Dahhan M, Lehner P, Turek T. Monoliths as multiphase reactors: a review. AIChE J 2004;50(11):2918-2938

14 Trinh TKH, de Hemptinne JC, Lugo R, Ferrando N, Passarello JP. Hydrogen solubility in hydrocarbon and oxygenated organic compounds. J Chem Eng Data 2016;61:19-34

15 Honda GS, Gase P, Hickman DA, Varma A. Hydrodynamics of trickle bed reactors with catalyst support particle size distributions. Ind Eng Chem Res 2014;53(22):9027-9034

16 Lopes RJG, Quinta-Ferreira RM. Numerical simulation of tricklebed reactor hydrodynamics with RANS-based models using a volume of fluid technique. Ind Eng Chem Res 2009;48(04): $1740-1748$

17 Khadilkar MR, Al-Dahhan MH, Duduković MP. Multicomponent flow-transport-reaction modeling of trickle bed reactors: application to unsteady state liquid flow modulation. Ind Eng Chem Res 2005;44(16):6354-6370

$18 \mathrm{Du} \mathrm{W}$, Zhang J, Lu P, et al. Advanced understanding of local wetting behaviour in gas-liquid-solid packed beds using CFD with a volume of fluid (VOF) method. Chem Eng Sci 2017; 170:378-392
19 Singh BK, Jain E, Buwa VV. Feasibility of electrical resistance tomography for measurements of liquid holdup distribution in a trickle bed reactor. Chem Eng J 2019;358:564-579

20 Al-Dahhan MH, Larachi F, Dudukovic MP, Laurent A. Highpressure trickle-bed reactors: a review. Ind Eng Chem Res 1997;36(08):3292-3314

21 Haure PH, Hudgins RR, Silveston PL. Periodic operation of a trickle-bed reactor. AIChE J 1989;35(09):1437-1444

22 Gallezot P, Nicolaus N, Flèche G, Fuertes P, Perrard A. Glucose hydrogenation on ruthenium catalysts in a trickle-bed reactor. J Catal 1998;180(01):51-55

23 Alonso F, Ancheyta J, Centeno G, Marroquín G, Rayo P, SilvaRodrigo R. Effect of reactor configuration on the hydrotreating of atmospheric residue. Energy Fuels 2019;33(02):1649-1658

24 Azarpour A, Rezaei N, Zendehboudi S. Dynamic modeling strategy to assess impacts of hydrodynamic parameters on industrial hydropurification process by considering catalyst deactivation. Ind Eng Chem Res 2018;57(41):13671-13688

25 Tirado A, Ancheyta J, Trejo F. Kinetic and reactor modeling of catalytic hydrotreatment of vegetable oils. Energy Fuels 2018;32 (07):72245-77261

26 Méndez CI, Ancheyta J, Trejo F. Modeling of catalytic fixed-bed reactors for fuels production by Fischer-Tropsch synthesis. Energy Fuels 2017;31(12):13011-13042

27 Murzin DY, Garcia S, Russo V, et al. Kinetics, modeling, and process design of hydrogen production by aqueous phase reforming of xylitol. Ind Eng Chem Res 2017;56(45): 13240-13253

28 Zaborenko N, Linder RJ, Braden TM, Campbell BM, Hansen MM, Johnson MD. Development of pilot-scale continuous production of an LY2886721 starting material by packed-bed hydrogenolysis. Org Process Res Dev 2015;19(09):1231-1243

29 Xi Y, Jackson JE, Miller DJ. Characterizing lactic acid hydrogenolysis rates in laboratory trickle bed reactors. Ind Eng Chem Res 2011;50(09):5440-5447

30 Newman SG, Lee K, Cai J, Yang L, Green WH, Jensen KF. Continuous thermal oxidation of alkenes with nitrous oxide in a packed bed reactor. Ind Eng Chem Res 2015;54(16):4166-4173

31 Samimi F, Ahmadi AR, Dehghani O, Rahimpour MR. DE approach in development of a detailed reaction network for liquid phase selective hydrogenation of methylacetylene and propadiene in a trickle bed reactor. Ind Eng Chem Res 2015;54(01):117-129

32 Kilpiö T, Biasi P, Bittante A, Salmi T, Wärnå J Modeling of direct synthesis of hydrogen peroxide in a packed-bed reactor. Ind Eng Chem Res 2012;51(41):13366-13378

33 Kilpiö T, Aho A, Murzin D, Salmi T. Experimental and modeling study of catalytic hydrogenation of glucose to sorbitol in a continuously operating packed-bed reactor. Ind Eng Chem Res 2013;52(23):7690-7703

34 Specchia V, Sicardi S, Gianetto A. Absorption in packed towers with concurrent upward flow. AIChE J 1974;20(04):646-653

35 Hirose T, Toda M, Sato Y. Liqusd phase mass transfer in packed bed reactor with cocurrent gas-liquid downflow. J Chem Eng of Jpn 1974;7(03):187-192

36 Goto S, Smith J. Trickle-bed reactor performance. Part I. Holdup and mass transfer effects. AIChE J 1975;21(04):706-713

37 Zheng Q Russo-Abegao FJ, Sederman AJ, Gladden LF. Operando determination of the liquid-solid mass transfer coefficient during 1-octene hydrogenation. Chem Eng Sci 2017;171:614-624

38 Metaxas K, Papayannakos N. Gas-liquid mass transfer in a benchscale trickle bed reactor used for benzene hydrogenation. Chem Eng Technol 2008;31(10):1410-1417

39 Stamatiou I, Muller FL. Determination of mass transfer resistances in trickle bed reactors. Chem Eng J 2019;377:119808

40 Iliuta I, Ortiz-Arroyo A, Larachi F, Grandjean BPA, Wild G. Hydrodynamics and mass transfer in trickle-bed reactors: an overview. Chem Eng Sci 1999;54(21):5329-5337 
41 Boelhouwer JG, Piepers HW, Drinkenburgh AAH. Nature and characteristics of pulsing flow in trickle-bed reactors. Chem Eng Sci 2002;2002(57):4865-4876

42 Roca E, Sanroman A, Núñez MJ, Lema JM. A pulsing device for packed bed bioreactors: I. Hydrodynamic behaviour. Bioprocess Eng 1994;10(02):61-73

43 Tsochatzidis NA, Karabelas AJ. Properties of pulsing flow in a trickle bed. AIChE J 1995;41(11):2371-2382

44 Wilhite BA, Huang X, McCready MJ, Varma A. Effects of induced pulsing flow on trickle-bed reactor performance. Ind Eng Chem Res 2003;42(10):2139-2145

45 Dankworth DC, Kevrekidis IG, Sundaresan S. Dynamics of pulsing flow in trickle beds. AIChE J 1990;36(04):605-621

46 Larachi F, Lliuta L, Chen M, Grandjean BPA. Onset of pulsing in trickle beds: evaluation of current tools and state-of-the-art correlation. Can J Chem Eng 2009;77(04):751-758

47 Honda GS, Lehmann E, Hickman DA, Varma A. Effects of prewetting on bubbly- and pulsing-flow regime transitions in tricklebed reactors. Ind Eng Chem Res 2015;54(42):10253-10259

48 Wang A, Marashdeh Q Motil BJ, Fan L-S. Electrical capacitance volume tomography for imaging of pulsating flows in a trickle bed. Chem Eng Sci 2014;119:77-87

49 Schubert M, Hessel G, Zippe C, Lange R, Hampel U. Liquid flow texture analysis in trickle bed reactors using high-resolution gamma ray tomography. Chem Eng J 2008;140(1-3):332-340

50 Aydin B, Fries D, Lange R, Larachi F. Slow-mode induced pulsing in trickle-bed reactors at elevated temperature. AIChE J 2006;52 (11):3891-3901

51 Wu R, McCready MJ, Varma A. Effect of pulsing on reaction outcome in a gas-liquid catalytic packed-bed reactor. Catal Today 1999;48(01):195-198

$52 \mathrm{Li}$ W, Zhao X, Liu B, Tang Z. Mass transfer coefficients for $\mathrm{CO}_{2}$ absorption into aqueous ammonia using structured packing. Ind Eng Chem Res 2014;53(14):6185-6196

53 Blok JR, Koning CE, Drinkenburg AAH. Gas-Liquid mass transfer in fixed-bed reactors with cocurrent downflow operating in the pulsing flow regime. AIChE J 1984;30(03):393-401

54 Gabitto JF, Lemcoff NO. Wall mass transfer coefficient in a trickle bed reactor. Chem Eng J 1985;30(01):23-27

55 Tajbl DG, Simons JB, Carberry JJ. Heterogeneous catalysis in continuous stirred tank reactor. Ind Eng Chem Fundam 1966;5 (02):171-175

56 Baronas R, Kulys J, Petkevicius L. Computational modeling of batch stirred tank reactor based on spherical catalyst particles. J Math Chem 2019;57:327-342

57 Wang S-N, Lan L, Hua W-B, et al. Ce-Zr-La/Al2O3 prepared in a continuous stirred-tank reactor: a highly thermostable support for an efficient Rh-based three-way catalyst. Dalton Trans 2015; 44(47):20484-20492

58 Cardona SC, Corma A. Tertiary recycling of polypropylene by catalytic cracking in a semibatch stirred reactor: use of spent equilibrium FCC commercial catalyst. Appl Catal B 2000;25(23):151-162

59 Benamara N, Assoua D, Jaffeux L, et al. A new concept of stirred multiphase reactor using a stationary catalytic foam. Processes (Basel) 2018;6(08):117

60 Sun Y, Yang G, Sun G, Sun Z, Zhang L. Performance study of stirred tank slurry reactor and fixed-bed reactor using bimetallic $\mathrm{Co}-\mathrm{Ni}$ mesoporous silica catalyst for fischer-tropsch synthesis. AIChE J 2018;37:553-561

61 Sedahmed GH, El-Taweel YA, Abdel-Aziz MH, El-Naqeara HM. Mass and heat transfer enhancement at the wall of cylindrical agitated vessel by turbulence promoters. Chem Eng Process 2014;80:43-50

62 Gu D, Liu Z, Tao C, Li J, Wang Y. Design of impeller blades for intersification of gas-liquid dispersion process in a stirred tank. Int J Chem React Eng 2018;16(12):1-16
63 Atef NM, Abdel-Aziz MH, Fouad YO, Farag HA, Sedahmed GH. Mass and heat transfer at an array of horizontal cylinders placed at the bottom of a square agitated vessel. Chem Eng Res Des 2015;94:449-455

64 Issa HM. Power consumption, mixing time and oxygen mass transfer in a gas-liquid contactor stirred with a duel impeller for different spacing. J Eng (Stevenage) 2016;2016:3954305

65 Karanth S, Thirmalesh BS. Mass transfer studies in an agitated vessel with radial-axial impeller combination. IJRETS 2015;4 (07):13-16

66 Prasher BB, Wills GB. Mass transfer in an agitated vessel. Ind Eng Chem Process Des Dev 1973;12(03):351-354

67 Barigou M, Greaves M. Bubble-size distributions in a mechanically agitated gas-liquid contactor. Chem Eng Sci 1992; 47:2009-2025

68 Lee JH, Foster NR. Measurement of gas-liquid mass transfer in multi-phase reactors. Appl Catal 1990;63(01):1-36

69 Karadagli F, Marcus AK, Rittmann BE. Role of hydrogen $\left(\mathrm{H}_{2}\right)$ mass transfer in microbiological $\mathrm{H}_{2}$-threshold studies. Biodegradation 2019;30(2-3):113-125

70 Munasinghe PC, Khanal SK. Evaluation of hydrogen and carbon monoxide mass transfer and a correlation between the myoglobin-protein bioassay and gas chromatography method for carbon monoxide determination. RSC Advances 2014;4:37575-37581

71 Dupnock TL, Deshusses MA. Detailed investigations of dissolved hydrogen and hydrogen mass transfer in a biotrickling filter for upgrading biogas. Bioresour Technol 2019;290:121780-121788

72 Rodenas P, Zhu F, Ter Heijne A, Sleutels T, Saakes M, Buisman C. Gas diffusion electrodes improve hydrogen gas mass transfer for a hydrogen oxidizing bioanode. J Chem Technol Biotechnol 2017; 92(12):2963-2968

73 Kara M, Sung S, Klinzing GE, Chiang SH. Hydrogen mass transfer in liquid hydrocarbons at elevated temperatures and pressures. Fuel 1983;62(12):1492-1498

74 Miller SA, Ekstrom A, Foster NR. Solubility and mass-transfer coefficients for hydrogen and carbon monoxide in n-octacosane. J Chem Eng Data 1990;(02):125-127

75 Blakebrough N, Sambamurthy K. Mass transfer and mixing rates in fermentation vessels. Biotechnol Bioeng 1966;8(01):25-42

76 Murthy BN, Ghadge RS, Joshi JB. CFD simulations of gas-liquidsolid stirred reactor: Prediction of critical impeller speed for solid suspension. Chem Eng Sci 2007;62(24):7184-7195

77 Yang S, Li X, Yang C, Ma B, Mao Z-S. Computational fluid dynamics simulation and experimental measurement of gas and solid holdup distributions in a gas-liquid-solid stirred reactor. Ind Eng Chem Res 2016;55:3276-3286

78 Kundu A, Dumont E, Duquenne A-M, Delmas H. Mass transfer characteristics in gas-liquid-liquid system. Can J Chem Eng 2008; 81(3-4):640-646

79 Bashiri H, Bertrand F, Chaouki J. Development of a multiscale model for the design and scale up of gas/liquid stirred tank reactors. Chem Eng J 2016;297:277-294

80 Li X, Scott K, Kelly WJ, Huang Z. Development of a computational fluid dynamics model for scaling up AMBR bioreactors. Biotechnol Bioproc E 2018;23(06):710-725

81 Stenberg O, Andersson B. Gas-liquid mass transfer in agitated vessels - II. Modelling of gas-liquid mass transfer. Chem Eng Sci 1988;43(03):725-730

82 Wutz J, Lapin A, Siebler F, et al. Predictability of kLa in stirred tank reactors under multiple operating conditions using an Euler-Lagrane approach. Eng Life Sci 2016;00:1-10

83 Amer M, Feng Y, Ramsey JD. Using CFD simulations and statistical analysis to correlate oxygen mass transfer coefficient to both geometrical parameters and operating conditions in a stirredtank bioreactor. Biotechnol Prog 2019;35(03):e2785

84 Stoian D, Eshtiaghi N, Wu J, Parthasarathy R. Enhancing impeller power efficiency and solid-liquid mass transfer in an agitated 
vessel with dual impellers through process intensification. Ind Eng Chem Res 2017;56(24):7021-7036

85 Stoian D, Eshtiaghi N, Wu J, Parthasarathy R. Solid-liquid mass transfer in sonicated agitated vessels with high concentration slurries. Heat Mass Transf 2019;55(05):1327-1335

86 Grisafi F, Brucato A, Rizzuti L. Solid-liquid mass transfer coefficients in gas-solid-liquid agitated vessels. Can J Chem Eng 1998;76(03):446-455

87 Dohi N, Takahashi T, Minekawa K, Kawase Y. Power consumption and solid suspension performance of large-scale impellers in gas-liquid-solid three-phase stirred tank reactors. Chem Eng J 2004;97(2-3):103-114

88 Ascanio G, Castro B, Galindo E. Measurement of power consumption in stirred vessels-a review. Chem Eng Res Des 2004;82(09): $1282-1290$

89 Zhang J, Gao Z, Cai Y, Cao H, Cai Z, Bao Y. Power consumption and mass transfer in a gas-liquid-solid stirred tank reactor with various triple-impeller combinations. Chem Eng Sci 2017; 170:467-475

90 Houcine I, Plasari E, David R. Effects of the stirred tank's design on power consumption and mixing time in liquid phase. Chem Eng Technol 2000;23(07):605-613

91 Armenante PM, Mazzarotta B, Chang G-M. Power consumption in stirred tanks provided with multiple pitched-blade turbines. Ind Eng Chem Res 1999;38(07):2809-2816

92 Holland IA, Chapman FS. Liquid Mixing and Processing in Stirred Tanks. New York, NY: Reinhold; 1966

93 Nienow AW, Lilly MD. Power draw by multiple impellers in sparged agitated vessels. Biotechnol Bioeng 1979;21:2341-2345

94 Nienow AW, Miles D. A dynamometer for the accurate measurement of mixing torque. J Phys E Sci Instrum 1969;2(11):994-995

95 Zhou R, Yang N, Li J. CFD simulation of gas-liquid-solid flow in slurry bubble columns with EMMS drag model. Powder Technol 2017;314(01):466-479

96 Besagni G, Inzoli F, Ziegenhein T, Lucas D. Computational fluiddynamic modeling of the pseudo-homogeneous flow regime in large-scale bubble columns. Chem Eng Sci 2016;160(16): 144-160

97 Fletcher DF, McClure DD, Kavanagh JM, Barton GW. CFD simulation of industrial bubble columns: numerical challenges and model validation successes. Appl Math Model 2017;44:25-42

98 Li Z, Guan X, Wang L, Cheng Y, Li X. Experimental and numerical investigations of scale-up effects on the hydrodynamics of slurry bubble columns. Chin J Chem Eng 2016;24(08):963-971

99 Magnini M, Ferrari A, Thome JR, Stone HA. Undulations on the surface of elongated bubbles in confined gas-liquid flows. Phys Rev Fluids 2017;2:084001

100 Jhawar AK, Prakash A. Heat transfer in a slurry bubble column reactor: a critical overview. Ind Eng Chem Res 2012;51(04): 1464-1473

101 Abdulrahman MW. CFD simulations of direct contact volumetric heat transfer coefficient in a slurry bubble column at a high gas temperature of a helium-water-alumina system. Appl Therm Eng 2016;99(25):224-234

102 Akita K, Yoshida F. Bubble size, interfacial area and liquid-phase mass transfer coefficient in bubble columns. Ind Eng Chem Process Des Dev 1974;13(01):84-91

103 Briens CL, Huynh LX, Large JF, Catros A, Bernard JR, Bergougnou MA. Hydrodynamics and gas-liquid mass transfer in a downward Venturi-bubble column combination. Chem Eng Sci 1992; 47:3549-3556

104 Hay JM, Hudson C, Briens CL. Correlation dimension for a gassolid contactor. Chem Eng J 1996;64:157-167

105 Wang T, Wang J, Jin Y. Slurry reactors for gas-to-liquid processes: a review. Ind Eng Chem Res 2007;46(18):5824-5847

106 Bouaifi M, Hebrard G, Bastoul D, Roustan M. A comparative study of gas holdup, bubble size, interfacial area and mass transfer coefficients in stirred gas-liquid reactors and bubble columns. Chem Eng Process 2001;40(02):97-111

107 Basha OM, Sehabiague L, Abdel-Wahab A, Morsi BI. FischerTropsch synthesis in slurry bubble column reactors: experimental investigations and modeling - a review. Int J Chem React Eng 2015;13(03):201-288

108 Seyednejadian S, Rauch R, Bensaid S, Hofbauer H, Weber G, Saracco G. Power to fuels: dynamic modeling of a slurry bubble column reactor in lab-scale for fischer tropsch synthesis under variable load of synthesis gas. Appl Sci (Basel) 2018;8:514-519

109 Meng F, Li X, Li M, Cui X, Li Z. Catalytic performance of CO methanation over La-promoted $\mathrm{Ni} / \mathrm{Al} 2 \mathrm{O} 3$ catalyst in a slurry-bed reactor. Chem Eng J 2017;313(01):1548-1555

110 Muharam Y, Adevia RT. Modelling and simulation of a slurry bubble column reactor for green fuel production via hydrocracking of vegetable oil. E3S Web Conf 2018;67:p02032

111 Balamurugan S, Lad MD, Gaikar VG, Patwardhan AW. Hydrodynamics and mass transfer characteristics of gas-liquid ejectors. Chem Eng J 2007;131:83-103

112 Sharma DV, Patwardhan AW, Ranade VV. Estimation of gas induction in jet loop reactors: influence of nozzle designs. Chem Eng Res Des 2017;125:24-34

113 Li WF, Wei Y, Tu GY, Shi ZH, Liu HF, Wang FC. Experimental study about mixing characteristic and enhancement of T-jet reactor. Chem Eng Sci 2016;144:116-125

114 Mandal A. Characterization of gas-liquid parameters in a down-flow jet loop bubble column. Braz J Chem Eng 2010;27(02):253-264

115 Ludwig W, Szafran RG, Kmiec A, Dziak J. Measurements of flow hydrodynamics in a jet-loop reactor using piv method. Procedia Eng 2012;42:1157-1168

116 Yamagiwa K, Kusabiraki D, Ohkawa A. Gas holdup and gas entrainment rate in downflow bubble column with gas entrainment by a liquid jet operating at high liquid throughput. JCEJ 1990;23:343-348

117 Atkinson BW, Jameson GJ, Nguyen AV, Evans GM, Machniewski PM. Bubble breakup and coalescence in a plunging liquid jet bubble column. Can J Chem Eng 2003;81:519-527

118 Bi R, Tang JT, Wang L, et al. Experimental study on bubble size distribution in gas-liquid reversed jet loop reactor. Int J Chem React Eng 2019;18:102-106

119 Warnecke HJ, Geisendörfer M, Hempel DC. Mass transfer behaviour of gas-liquid jet loop reactors. Chem Eng Technol 1988; 11:306-311

120 Warmeling H, Behr A, Vorholt AJ. Jet loop reactors as a versatile reactor set up - Intensifying catalytic reactions: a review. Chem Eng Sci 2016;149:229-248

121 Burke U, Metcalfe WK, Burke SM, Heufer KA, Dagaut P, Curran HJ. A detailed chemical kinetic modeling, ignition delay time and jet-stirred reactor study of methanol oxidation. Combust Flame 2016;165:125-136

122 Fedavi A, Chisti Y, Chriastel L. Bubble size in a forced circulation loop reactor. J Chem Technol Biotechnol 2008;83(01):105-108

123 Padmavathi G, Remananda Rao K. Hydrodynamic chacteristics of reversed flow jet loop reacctor as a gas-liquid-solid contactor. Chem Eng Sci 1991;46(02):3293-3296

124 Esteban J, Warmeling H, Vorholt AJ. An approach to chemical reaction engineering and process intensification for the lean aqueous hydroformylation using a jet loop reactor. Chemieingenieurtechnik (Weinh) 2019;91(05):1-8

125 Norman Herrmann N, Bianga J, Palten M, et al. Improving aqueous biphasic hydroformylation of unsaturated oleochemicals using a jet-loop-reactor. Eur J Lipid Sci Technol 2019;122 (01):1900166

126 Cha G-E, Sung H-J, Lim J-H, Lee T-Y, Lee J-K. $\mathrm{CO}_{2}$ absorption characteristics of a jet loop reactor with a two-fluid swirl nozzle in an alkaline solution. Korean J Chem Eng 2014;31 (04):701-705 
127 Khoufi S, Louhichi A, Sayadi S. Optimization of anaerobic codigestion of olive mill wastewater and liquid poultry manure in batch condition and semi-continuous jet-loop reactor. Bioresour Technol 2015;182:67-74

128 Farizoğlu B, Uzuner S. Design of a novel membrane draft tube jet loop reactor (MDJLR) and treatment of slaughterhouse wastewater. Membranes (Basel) 2019;9(11):155

129 Wen J, Wang C. The preparation of imidacloprid in a jet loop reactor. Chem Eng Commun 2005;192:286-294

130 Ughetti M, Jussen D, Riedlberger P. The ejector loop reactor: application for microbial fermentation and comparison with a stirred-tank bioreactor. Eng Life Sci 2018;18(05):281-286

131 Zhang C, Qian WZ, Wang Y, Luo G. Heterogeneous catalysis in multi-stage fluidized bed reactors: from fundamental study to industrial application. Can J Chem Eng 2018;97(03):233-239

132 Grace JR. Fluidized-bed catalytic reactors. In: Onsan ZI, Avci AK, eds. Multiphase Catalytic Reactors: Theory, Design, Manufacturing, and Applications. Hoboken, NJ: John Wiley \& Sons, Inc.; 2016:80-93

133 Smith JM. Large multiphase reactors: some open questions. Chem Eng Res Des 2006;84(04):265-271

134 Pangarkar VG. Process intensification in multiphase reactors: from concept to reality. Chem Eng Process 2017;120:1-8

135 Duduković MP, Larachi F, Mills PL. Multiphase catalytic reactors: a perspective on current knowledge and future trends. Catal Rev 2007;44(01):123-246

136 Humphrey DW, Van Ness HC. Mass transfer in a continuous-flow mixing vessel. AIChE J 1957;3:283-286

137 Shapiro OH, Fernandez VI, Garren M, et al. Vortical ciliary flows actively enhance mass transport in reef corals. Proc Natl Acad Sci U S A 2014;111(37):13391-13396

138 Ansari M, Turney DE, Yakobov R, Banerjee S, Joshi JB. Hydrodynamics under the jet-array of a downflow bubble column: process intensification. Chem Eng Process 2018;130:326-331

139 Muroyanma K, Imai K, Oka Y, Hayashi J. Mass transfer properties in a bubble column associated with micro-bubble dispersions. Chem Eng Sci 2013;100:464-473

140 Maldonado SL, Rasch D, Kasjanow A, Bouwes D, Krühne U, Krull R. Multiphase microreactors with intensification of oxygen mass transfer rate and mixing performance for bioprocess development. Biochem Eng J 2018;139:57-67

141 Yue J. Multiphase flow processing in microreactors combined with heterogeneous catalysis for efficient and sustainable chemical synthesis. Catal Today 2018;308:3-19

142 Inoue T, Schmidt MA, Jensen KF. Microfabricated multiphase reactors for the direct synthesis of hydrogen peroxide from hydrogen and oxygen. Ind Eng Chem Res 2007;46(04):1153-1160

143 Rebrov E, Chatterjee S. Microreactors for catalytic reactions. In: Onsan ZI, Avci AK, eds. Multiphase Catalytic Reactors: Theory, Design, Manufacturing, and Applications. Hoboken, NJ: John Wiley \& Sons, Inc; 2016:213-228

144 Duduković MP, Mills PL. Scale-up and multiphase reaction engineering. Curr Opin Chem Eng 2015;9:49-58

145 Jealous AC, Johnson HF. Power requirements for pulse generation in pulse columns. Ind Eng Chem 1955;47(06):1159-1166

146 Jimeno Miller G, Ni X. On the evaulation of power density models for oscillatory baffled crystallizer using CFD. Chem Eng Process 2018;134:153-162
147 Baird MHI, Stonestreet P. Energy dissipation in oscillatory flow within a baffled tube. Chem Eng Res Des 1995;73(A5):503-511

148 Avila M, Fletcher D, Poux M, Xuereb C, Aubin J. Predicting power consumption in continuous oscillatory baffled reactors. Chem Eng Sci 2019;212:115310

$149 \mathrm{Ni}$ X, Gao S. Mass transfer characteristics of a pilot pulsed baffled reactor. J Chem Technol Biotechnol 1996;65(01):65-71

150 Gao S. Characterisation of Pulsed Baffled Reactors [PhD thesis]. Strathclyde University; 1996

151 Hewgill MR, Mackley MR, Pandit AB, Pannu SS. Enhancement of gas-liquid mass transfer using oscillatory flow in a baffled tube. Chem Eng Sci 1993;48(04):799-809

152 Ni X, Gao S, Cumming RH, Pritchard DW. A comparative study of mass transfer in yeast for a batch pulsed baffled bioreactor and a stirred tank fermenter. Chem Eng Sci 1995;50(13):2127-2136

153 Ferreira A, Teixeira JA, Rocha FO. 2 mass transfer in an oscillatory flow reactor provided with smooth periodic constrictions. Individual characterisation of $\mathrm{kL}$ and a. Chem Eng J 2015; 262:499-508

154 Reis N, Pereira RN, Vicente AA, Teixeira JA. Enhanced gas-liquid mass transfer of an oscillatory constricted-tubular reactor. Ind Eng Chem Res 2008;47(19):7190-7201

155 Al-Abduly A, Christensen P, Harvey A, Zahng K. Characterization and optimization of an oscillatory baffled reactor (OBR) for ozone-water mass transfer. Chem Eng Process 2014;84:82-89

156 Graça CAL, Lima RB, Pereira MFR, Silva AMT, Ferreira A. Intensification of the ozone-water mass transfer in an oscillatory flow reactor with innovative design of periodic constrictions: optimization and application in ozonation water treatment. Chem Eng J 2020;389:124412

157 Pereira FM, Sousa DZ, Alves MM, Mackley MR, Reis NM. $\mathrm{CO}_{2}$ dissolution and design aspects of a multiorifice oscillatory baffled column. Ind Eng Chem Res 2014;53(44):17303-17316

158 Navarro Fuentes F, Keane MA, Ni X. A comparative evaluation of hydrogenation of 3-butyn-2-ol over Pd/Al2O3 in an oscillatory baffled reactor and a commercial PARR reactor. Org Process Res Dev 2018;23(01):38-44

159 Moucha T, Linek V, Prokopova E. Gas hold-up, mixing time and gas-liquid volumetric mass transfer coefficient of various multiple-impeller configurations: Rushton turbine, pitched blade and techmix impeller and their combinations. Chem Eng Sci 2003;58(09):1839-1846

160 Garcia-Ochoa F, Gomez E. Theoretical prediction of gas-liquid mass transfer coefficient, specific area and hold-up in sparged stirred tanks. Chem Eng Sci 2004;59:2489-2501

161 Devi TT, Kumar B. Mass transfer and power characteristics of stirred tank with Rushton and curved blade impeller. Eng Sci Technol 2017;20:730-737

162 Prasad KY, Ramanujam TK. Enhancement of gas-liquid mass transfer in a modified reversed flow jet loop reactor with three phase system. Chem Eng Sci 1995;50(18):2997-3000

163 Evans GM, Bin AK, Machniewski PM. Performance of confined plunging liquid jet bubble column as a gas-liquid reactor. Chem Eng Sci 2001;56:1151-1157

164 Terasaka K, Hirabayashi A, Nishino T, Fujioka S, Kobayashi D. Development of microbubble aerator for waste water treatment using aerobic activated sludge. Chem Eng Sci 2011;66: 3172-3179 